\title{
Fit-for-purpose phosphorus management: do riparian buffers qualify in catchments with sandy soils?
}

\author{
David Weaver • Robert Summers
}

Received: 17 May 2013 / Accepted: 12 December 2013 / Published online: 7 January 2014

(C) The Author(s) 2014. This article is published with open access at Springerlink.com

\begin{abstract}
Hillslope runoff and leaching studies, catchment-scale water quality measurements and $\mathrm{P}$ retention and release characteristics of stream bank and catchment soils were used to better understand reasons behind the reported ineffectiveness of riparian buffers for phosphorus (P) management in catchments with sandy soils from south-west Western Australia (WA). Catchment-scale water quality measurements of $60 \%$ particulate $\mathrm{P}$ (PP) suggest that riparian buffers should improve water quality; however, runoff and leaching studies show 20 times more water and 2 to 3 orders of magnitude more $\mathrm{P}$ are transported through leaching than runoff processes. The ratio of filterable reactive $\mathrm{P}$ (FRP) to total $\mathrm{P}(\mathrm{TP})$ in surface runoff from the plots was $60 \%$, and when combined with leachate, 96 to $99 \%$ of P lost from hillslopes was FRP, in contrast with $40 \%$ measured as FRP at the large catchment scale. Measurements of the $\mathrm{P}$ retention and release characteristics of catchment soils $(<2 \mathrm{~mm})$ compared with stream bank soil $(<2 \mathrm{~mm})$ and the $<75-\mu \mathrm{m}$ fraction of stream bank soils suggest that catchment soils contain more $\mathrm{P}$, are more $\mathrm{P}$ saturated and are significantly more likely to deliver FRP and TP in excess of water quality targets
\end{abstract}

\footnotetext{
D. Weaver $(\bowtie)$

Department of Agriculture and Food-Western Australia, 444 Albany Hwy, Albany, Western Australia 6330, Australia e-mail: david.weaver@agric.wa.gov.au

R. Summers

Department of Agriculture and Food-Western Australia, 120 South Western Highway,

Waroona, Western Australia 6215, Australia

e-mail: robert.summers@agric.wa.gov.au
}

than stream bank soils. Stream bank soils are much more likely to retain $\mathrm{P}$ than contribute $\mathrm{P}$ to streams, and the instream mixing of FRP from the landscape with particulates from stream banks or stream beds is a potential mechanism to explain the change in $\mathrm{P}$ form from hillslopes (96 to $99 \%$ FRP) to large catchments (40\% FRP). When considered in the context of previous work reporting that riparian buffers were ineffective for $\mathrm{P}$ management in this environment, these studies reinforce the notion that (1) riparian buffers are unlikely to provide fit-for-purpose $\mathrm{P}$ management in catchments with sandy soils, (2) most P delivered to streams in sandy soil catchments is FRP and travels via subsurface and leaching pathways and (3) large catchment-scale water quality measurements are not good indicators of hillslope $\mathrm{P}$ mobilisation and transport processes.

Keywords Sediment · Riparian buffers · Soluble · Filterable reactive phosphorus $\cdot$ Leaching .

Subsurface flow

\section{Introduction}

Phosphorus $(\mathrm{P})$ and nitrogen $(\mathrm{N})$ loss from landscapes to waterways has been identified as a key influence over the frequency and intensity of algal blooms (Sharpley et al. 1994; Daniel et al. 1994). To minimise nutrient loss and the threat of algal blooms, a range of nutrient management practices have been proposed, tested, modelled and implemented. These practices and tools include fertiliser management (timing, solubility, soil 
testing), effluent management (land disposal, artificial fertiliser substitution), soil amendment (increased $\mathrm{P}$ retention for sandy soils), perennial pastures and riparian buffers (fencing, stock exclusion, off-stream stock watering, stock and vehicle crossings; Keipert et al. 2008; Neville et al. 2008). Riparian buffers provide a multitude of functions such as stabilisation of channels, filtration of nutrients and sediment, and ecosystem services such as water purification by controlling pathogens and bacteria (Barling and Moore 1994). Whilst some studies suggest that riparian buffers can reduce $\mathrm{P}$ loss by $90 \%$ (Line et al. 2000), others suggest that buffer strips may offer a temporary solution as sinks in some years and sources in others (Omernik et al. 1981). McKergow et al. (2003) showed no impact of riparian buffers on P delivery in Western Australia (WA) whilst Stutter et al. (2009) identified various biogeochemical mechanisms by which riparian buffers could contribute to increased P losses. Given that riparian buffers have been variously reported as contributing to $\mathrm{P}$ retention and $\mathrm{P}$ loss, it is important to understand the key factors and mechanisms contributing to the diversity of riparian buffer effectiveness in P management.

Hoffman et al. (2009) emphasised the need to identify and quantify the major hydrological pathways in order to understand the ability of riparian buffers to mitigate $\mathrm{P}$ transport. This is because the mechanisms that support $\mathrm{P}$ retention are likely to be different for systems dominated either by overland flow or subsurface flow. For overland flow, riparian buffer strips function to filter nutrients associated with sediment by physically filtering and trapping hillslope-derived particulate $\mathrm{P}$ (PP) in surface runoff. Riparian buffers can also reduce stream bank and bed erosion and hence reduce $P$ delivery from the erosion of high $\mathrm{P}$ subsoils (Laubel et al. 2003). When subsurface flow pathways dominate, $\mathrm{P}$ sorption properties of soil and sediment and their hydrologic properties become more important. Hoffman et al. (2009) reported for systems dominated by overland flow that total P (TP) was reduced by $32-93 \%$, whereas dissolved reactive $\mathrm{P}$ (DRP) had a net release of $71 \%$ up to a net retention of $95 \%$. Physical processes such as sedimentation of PP appears to account for the most P reduction by riparian buffers (up to $128 \mathrm{~kg}$ $\mathrm{P} \mathrm{ha}^{-1}$ year $^{-1}$ ), followed by biological processes through plant uptake that can temporarily retain up to $15 \mathrm{~kg}$ $\mathrm{P} \mathrm{ha}^{-1}$ year $^{-1}$, whilst the retention of DRP is often below $0.5 \mathrm{~kg} \mathrm{P} \mathrm{ha}{ }^{-1}$ year $^{-1}$ (Hoffman et al. 2009). Previous riparian studies in south-west WA (McKergow et al.
2003, 2006a, b) identified that subsurface transport pathways were an important factor in limiting the effectiveness of riparian buffers for $\mathrm{P}$ management. McKergow et al. (2003) also proposed that the presence of buffers may reduce suspended sediment (SS) concentrations in streams to such an extent that DRP concentrations can increase because of reduced $\mathrm{P}$ sorption potential that would otherwise be provided by the SS, prior to deposition and retention in the stream bed.

McDowell et al. (2004) cited numerous sedimentary, biotic, chemical, hydrological and physical processes that may alter the retention, release or transformation of $\mathrm{P}$ once it has entered a stream. Additionally, McDowell and Sharpley (2001) compared deposited stream bank and stream bed sediment $\mathrm{P}$ chemistry and noted that bed sediments were more likely to release $\mathrm{P}$ and stream bank sediment was more likely to retain P. Stone and Mudroch (1989) noted that $P$ release and retention within streams was inversely related to particle size and P sorption capacity of suspended material, suggesting that hydrological processes controlling sediment particle size has implications for P delivery and fate in river systems. All of these factors and their interactions are likely to significantly alter water quality signatures such that they cannot always be interpreted as reflecting the process by which $\mathrm{P}$ was mobilised and transported from the landscape, although there are clearly instances where they are (van der Perk et al. 2007). These observations suggest that reliance on catchment-based water quality signatures that show high levels of PP as an indicator that P mobilisation and transport processes are dominated by surface erosion and runoff seems problematic. Further investigation was considered warranted based on evidence gained in WA.

For example, a coarse-scale national audit and modeling of catchments, rivers and estuaries in Australia (NLWRA 2002) indicated that for south-west WA, SS supply was on average 0.3 tonnes $\mathrm{ha}^{-1}$ year $^{-1}$ (range $0.1-$ 0.6 tonnes $\mathrm{ha}^{-1}$ year $^{-1}$ ) and that $4 \%$ (range $0.7-21 \%$ ), $70 \%$ (range $52-83 \%$ ) and $26 \%$ (range $14-45 \%$ ) of the SS was derived on average from hillslope, gully and bank erosion, respectively. NLWRA (2001) similarly reported for south-west WA that 3, 49, 14, 7 and $27 \%$ of the P loss was from hillslope PP, gully erosion PP, bank erosion PP, point source DRP and runoff DRP, respectively. Based on this data, it seems unlikely in this region that SS and PP would be derived from surface erosion, yet riparian buffers are often implemented or proposed (Environmental Protection Authority 2008; Department of Water, WA 
2010; Department of Water 2011) as a principal control for diffuse pollution, despite their reported limited effectiveness in this environment (McKergow et al. 2003, 2006a, b). Implementation often occurs without cognizance of the dominant hydrological pathways (Ruprecht and George 1993), P forms and transport pathways, or their cost effectiveness compared to other nutrient management practices (Weaver et al. 2005). In order for riparian buffers to meet site-specific requirements, scientists and managers need to be sure that the practice can provide "fit for purpose" $\mathrm{P}$ management benefits by considering local data sources and studies that (1) identify the dominant hydrological and contaminant pathways, (2) identify the nutrient forms being transported from hillslopes to buffers, (3) identify whether catchment-scale water quality signatures reflect landscape $\mathrm{P}$ delivery processes or may be subsequently modified by other in-stream processes and (4) consider whether the practice contributes to pollution swapping or has other adverse impacts (Stevens and Quinton 2008).

The objectives of this study based in south-west WA were to better understand the reasons behind the reported ineffectiveness of riparian buffers and to evaluate whether riparian buffers provide a fit-for-purpose solution for P management in catchments where sandy soils dominate. Data and findings from various studies in south-west WA were assembled to assist in understanding the role of riparian buffers to manage $\mathrm{P}$ in environments where sandy soils dominate. Dominant hydrological and $\mathrm{P}$ pathways and $\mathrm{P}$ forms delivered from hillslopes through different pathways were studied using runoff plots. Additionally, catchment water quality studies and $\mathrm{P}$ retention and release characteristics of stream bank and catchment soils were used to explore the potential for water quality signatures to reflect landscape $\mathrm{P}$ delivery processes. The findings are discussed in the context of other local studies that reported limited effectiveness of riparian buffers for $\mathrm{P}$ management (McKergow et al. 2003, 2006a, b), and conceptual models to support these findings are proposed.

\section{Materials and methods}

\section{Catchment environment}

A Mediterranean climate, with cool wet winters and dry, temperate summers, typifies the region (Fig. 1). Annual average rainfall follows a strong gradient from $400 \mathrm{~mm}$ in the north-east of the region to $1,200 \mathrm{~mm}$ near the coast and dominates the winter months from April to October. The landscape comprises gently undulating plains developed mainly on tertiary sediments with occasional granitic hills (Churchward et al. 1988). Duplex soils are common with shallow grey acidic siliceous sands overlying laterite and clay at higher elevations and sands and sandy gravels at lower elevations, and valleys often comprise deep sands. The most common soil groups (duplex sandy gravel, grey deep sandy duplex and pale deep sandy soil) represent around $50 \%$ of the study area (Schoknecht 2005). A land surface slope classification of the Oyster Harbour catchment on the south coast of WA (Fig. 1) shows that around $65 \%$ has a slope of $<4 \%$ (Master 2007). Sixty percent of the study area was identified as having a potential for nutrient leaching, whilst only $15 \%$ had a potential for surface soil erosion (Weaver et al. 2005). In the very flat catchment of the Peel-Harvey estuary on the west coast of WA, Ruprecht and George (1993) suggested that for deep sands, groundwater is permanently close to the surface $(\sim 1 \mathrm{~m})$ and rises to provide overland flow in major storm events. Around $60 \%$ of the P load for deep sands is transported by subsurface throughflow. For these duplex soils of the Peel-Harvey catchment, Ruprecht and George (1993) suggested that only around $25 \%$ of the P load was transported by subsurface throughflow because of very low slopes and saturation of the sandy A horizon. The slope of the land surface in the south coast catchments under study here is greater than that of the Peel-Harvey, providing better drainage, resulting in more discharge via the $\mathrm{B}$ horizon subsurface pathways than via surface pathways or the A horizon (McKergow et al. 2006a). High subsurface flows only occur during winter, and high saturated conductivities (up to $18 \mathrm{~m} \mathrm{day}^{-1}$ ) limit the residence time of water in subsurface soil layers. Piezometer and subsurface flow measurements suggest that subsurface flow contributes rapidly to streamflow during rainfall events, assisted by pockets of gravel, sharp soil horizon boundaries and macropores (McKergow et al. 2006a).

Around two-thirds of the landscape has been cleared of natural vegetation and replaced with agriculture, with most of the clearing taking place in the 1950s and 1960s. Around one-third of the landscape is used each for grazing, cereal cropping and natural vegetation (NLWRA 2001). Agriculture is typified by broadscale grazing of annual subterranean clovers (Trifolium 


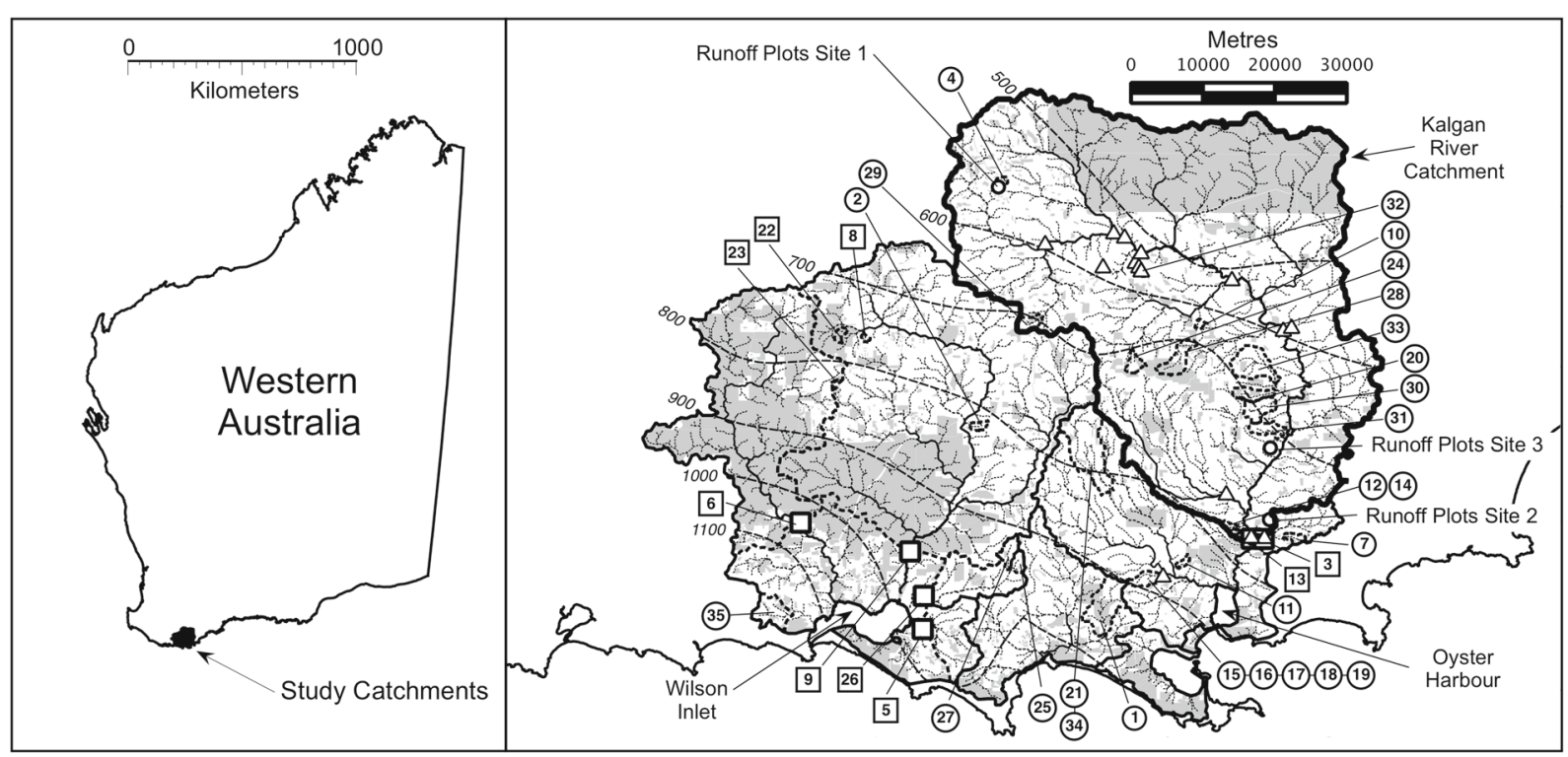

Fig. 1 Left panel: Overview map showing the location of the study catchments in Western Australia. Right panel: Major catchment boundaries (solid line), Kalgan River catchment boundary (thick solid line), vegetation (shaded), stream network and rainfall isohyets (dashed lines). Runoff trial locations (open circles),

subterraneum L.) and ryegrass for cattle and sheep in areas with higher rainfall ( $>600 \mathrm{~mm}$ annually), with the extent of cereal cropping increasing as rainfall decreases to $<600 \mathrm{~mm}$ annually. Cereal cropping is supported by the use of minimum tillage. In their natural state, the soils are $\mathrm{P}$ deficient and will respond to applied fertiliser P. Fertiliser practice is typically based around tradition, with annual $\mathrm{P}$ applications of $10-15 \mathrm{~kg} \mathrm{P} \mathrm{ha}^{-1}$ year $^{-1}$, independent of crop or pasture requirements (Weaver and Reed 1998). Many soils (63\% of pasture, $87 \%$ of wheat, $89 \%$ of dairy) now contain $\mathrm{P}$ in excess of requirements (Weaver and Wong 2011).

\section{Hillslope P transport}

Runoff plots were established in three locations (upper, lower and bottom) in the Kalgan River catchment (the major tributary of Oyster Harbour, Fig. 1) on the south coast of WA in 1992 to assess the dominant hydrological and $\mathrm{P}$ pathways and to determine $\mathrm{P}$ leaching and runoff losses in relation to environmental conditions and $\mathrm{P}$ application over 2 years. The paddocks chosen had been used for agriculture, in particular the grazing of sheep or cattle on rain-fed annual pastures (ryegrass and subterranean clover), for around 30 years. At each location, monitored catchments (indicated by numbered circles and dashed catchment boundaries), location of stream bank sampling sites (open triangles) and Department of Water catchments (indicated by numbered squares and white filled squares). Refer to Table 1 to reconcile site numbers with summary water quality data

uniform slopes within selected paddocks were identified and soil samples (consisting of 50 0-10-cm cores bulked) were analysed for bicarbonate-extractable $\mathrm{P}$ (Colwell P; Colwell 1965), ammonium oxalate extractable iron (Amox Fe; Tamm 1922) and aluminium (Amox Al), Phosphorus Retention Index (PRI; Bolland and Windsor 2007) and $\mathrm{pH}$ to assist in the interpretation of water quality data collected from the plots (Table 3). Phosphorus saturation ratio (PSR) was estimated for collected soils using the molar ratio method described by Chrysostome et al. (2007), and soil P status was determined using critical levels to achieve $95 \%$ of maximum pasture production (Gourley et al. 2007). Six adjacent but hydrologically isolated plots ( $2 \mathrm{~m}$ wide and $40 \mathrm{~m}$ long) were established at each location. The plots were located midway down the slope and were hydrologically isolated by the use of a bund to ensure that there was no run on from the upper hillslope, and the use of $15-\mathrm{cm}$ fibre cement sheeting strips was inserted to a $10-\mathrm{cm}$ depth to ensure that there was no crossflow from adjacent plots. Surface runoff from each plot was directed into a covered $200-\mathrm{L}$ drum, where depths were measured and converted into volumes based on a simple depth/volume calibration. Lysimeters, $30-\mathrm{cm}$ diameter, were installed in the centre of each plot 
to determine volumes and quality of water leaching below $10 \mathrm{~cm}$ at each location. Three randomly selected plots at each location received the district average application of $10 \mathrm{~kg} \mathrm{P} \mathrm{ha}{ }^{-1}$ in mid-June each year as superphosphate, whilst the other three plots received no $\mathrm{P}$ application. Water volumes were measured at varying intervals to match significant rainfall events and were converted to millimetres of rainfall equivalents for analysis. Subsamples of runoff and leachate waters were retained for analysis. Runoff samples were analysed for TP and a filtered subsample $(<0.45 \mu \mathrm{m})$ for filterable reactive P (FRP), whilst leachate samples were analysed for FRP (APHA 1995). Water volumes and analyte concentrations were used to compute nutrient loads (kilograms per hectare) on an event and annual basis and aggregated according to specific analyses. Annual rainfall in each year of the trial was put into context with long-term annual rainfall at each site by comparing the rainfall against annual rainfall frequency distributions for data available since 1890 and 1975 (DSITIA 2013).

\section{Catchment $\mathrm{P}$ transport}

Discharge measurements were coupled with TP, FRP and SS concentrations (Kisters Pty Ltd 2013) to derive annual TP and FRP loads for a wide range of catchments (Table 1) in the study area (Fig. 1) and TP, FRP and SS loads for the Kalgan River (Table 2) catchment (AWMA 1995), for varying periods from 1988 to 2000. The collection of gauging sites included small-scale sites established to estimate nutrient loss rates from various land uses and landscapes and longer-term sites that are part of the hydrological network managed by the Department of Water, WA (http://www.water.wa.gov.au). Instantaneous discharge (cubic metres per second) was determined from rating curves or discharge measurement structures established at gauging sites (Fig. 1) coupled with loggers and probes measuring stream water levels. Opportunistically collected grab samples of water were supplemented with samples collected by automatic samplers and point integrated air-displacement samplers on the rising stage (Guy and Norman 1970) in order to chemically characterise hydrographs for monitored catchments and subcatchments. Total $\mathrm{P}$ was determined on unfiltered samples using persulphate digestion (APHA 1995), and FRP was determined on filtered samples $(<0.45 \mu \mathrm{m})$, both using the method of Murphy and Riley (1962). All unfiltered samples were also analysed for SS (APHA 1995; with a 1.2- $\mu \mathrm{m} \mathrm{GF/C} \mathrm{filter} \mathrm{paper).} \mathrm{Where} \mathrm{data} \mathrm{was}$ available, annual contaminant (TP, FRP, SS) loads were estimated by the integration of continuous discharge information with discontinuous time series chemistry. The contaminant load data were summarised by calculating the range and median with $95 \%$ confidence interval and estimating the proportion of $\mathrm{P}$ delivered as FRP by dividing the median FRP load by the median TP load. Estimates of the unweighted proportion of $\mathrm{P}$ delivered as FRP were also made by calculating the mean and $95 \%$ confidence interval of the ratios of measured FRP and TP concentrations at each site. The subcatchment- and catchment-scale data was compared to water quality data from runoff plots.

\section{$\mathrm{P}$ characteristics of catchment and stream bank soils}

Stream banks were sampled at 17 locations in the Oyster Harbour catchment to determine P content and P sorption characteristics in comparison to surface agricultural soils. Sites selected included currently eroding stream banks (Fig. 1, some sites overlap at the presented map scale). This was done to distinguish whether these materials would act as a P source or as a P sink for P lost through other pathways. Previous work in Australia had indicated that gully erosion could be a major P source contributing to downstream waterway pollution in comparison to other sources (Caitcheon et al. 1995). At each location, subsamples from eroding banks were combined to obtain a representative composite sample. Each stream bank sample was dried at $40{ }^{\circ} \mathrm{C}$ and fractionated into >1-, 0.6-1-, 0.3-0.6-, 0.15-0.3-, 0.075-0.15- and $<0.075$-mm-sized fractions. The fractions were analysed for total P after Kjeldahl digestion, Amox Fe and Amox Al (Tamm 1922), PRI (Bolland and Windsor 2007), bicarbonate-extractable P (Colwell P; Colwell 1965) and organic carbon (Walkley and Black 1934). Phosphorus saturation ratio (Chrysostome et al. 2007), Colwell P/PRI ratio and estimated FRP (Moody 2011) and TP (Dougherty et al. 2011b) concentrations likely to arise from soil or stream bank materials were derived. For all analytes or their derivatives, fractionated values were combined on a weight basis to derive analysis for whole stream bank materials. The whole stream bank data and the $<75-\mu \mathrm{m}$ fraction were compared with 422 surface $(0-10 \mathrm{~cm})$ samples of soil that had been collected in the study catchments. Soil samples underwent the same chemical analysis, but on bulk soil sieved to $<2 \mathrm{~mm}$. 
Table 1 Monitoring site numbers, catchment areas, median and range in TP and FRP loads, percentage of catchment and subcatchment $\mathrm{P}$ loads that is FRP, mean and $95 \%$ confidence interval of FRP/TP concentration ratios and mean and $95 \%$ confidence interval of unit area TP loads for sites in the study area
Number Catchment area (ha) Median load with range in parenthesis

$\mathrm{TP}(\mathrm{kg}) \quad$ FRP $(\mathrm{kg})$

FRP/TP load (\%) Median $\pm 95 \%$ confidence interval

Unit area TP FRP/TP

load $\left(\mathrm{kg} \mathrm{ha}^{-1}\right)$ concentration (\%)

\begin{tabular}{|c|c|c|c|c|c|c|}
\hline 1 & 2,078 & $3,696(1,560-4,353)$ & $2,716(1,194-3,055)$ & 73 & $1.57 \pm 0.63$ & $70 \pm 3$ \\
\hline 2 & 268 & $17(6-49)$ & $3(1-6)$ & 16 & $0.08 \pm 0.08$ & $37 \pm 5$ \\
\hline 3 & 5,185 & $429(137-3,055)$ & $213(181-1,528)$ & 50 & $0.18 \pm 0.12$ & $63 \pm 4$ \\
\hline 4 & 266 & $14(4-26)$ & $4(1-5)$ & 25 & $0.05 \pm 0.03$ & $27 \pm 4$ \\
\hline 5 & 3594 & $1,782(1,600-2,423)$ & $568(324-752)$ & 32 & $0.54 \pm 0.16$ & $28 \pm 5$ \\
\hline 6 & 64,127 & $930(523-2,098)$ & $247(145-405)$ & 27 & $0.02 \pm 0.02$ & $59 \pm 13$ \\
\hline 7 & 331 & $52(16-288)$ & $24(7-135)$ & 47 & $0.28 \pm 0.16$ & $62 \pm 5$ \\
\hline 8 & 105 & $5(5-14)$ & $0.6(0.2-1)$ & 11 & $0.08 \pm 0.05$ & $47 \pm 4$ \\
\hline 9 & 121,100 & $1,481(1,194-2,477)$ & $458(254-1,019)$ & 31 & $0.01 \pm 0.01$ & $65 \pm 11$ \\
\hline 10 & 150 & nd & nd & nd & nd & $39 \pm 6$ \\
\hline 11 & 189 & $92(52-197)$ & $29(13-147)$ & 32 & $0.63 \pm 0.39$ & $52 \pm 4$ \\
\hline 12 & 172 & $20(11-64)$ & nd & nd & $0.17 \pm 0.11$ & $79 \pm 4$ \\
\hline 13 & 244,571 & $5,853(316-41,534)$ & $1,460(574-3,689)$ & 25 & $0.05 \pm 0.02$ & $52 \pm 3$ \\
\hline 14 & 127 & $9(4-33)$ & nd & nd & $0.09 \pm 0.02$ & $84 \pm 0$ \\
\hline 15 & 183 & $9(6-18)$ & $2(2-10)$ & 26 & $0.06 \pm 0.03$ & $40 \pm 4$ \\
\hline 16 & 267 & $40(17-74)$ & $26(3-61)$ & 66 & $0.16 \pm 0.11$ & $60 \pm 4$ \\
\hline 17 & 294 & $30(20-71)$ & $13(5-48)$ & 44 & $0.13 \pm 0.08$ & $52 \pm 5$ \\
\hline 18 & 589 & $371(112-793)$ & $181(77-525)$ & 49 & $0.72 \pm 0.4$ & $65 \pm 2$ \\
\hline 19 & 649 & $122(70-274)$ & $89(54-222)$ & 73 & $0.23 \pm 0.14$ & $75 \pm 2$ \\
\hline 20 & 980 & nd & nd & nd & nd & $18 \pm 4$ \\
\hline 21 & 3,318 & $1,030(1,030-1,030)$ & 992 (992-992) & 96 & $0.31 \pm 0$ & $75 \pm 8$ \\
\hline 22 & 137 & $3(2-5)$ & $0.6(0.6-0.7)$ & 20 & $0.03 \pm 0.02$ & $50 \pm 15$ \\
\hline 23 & 115 & $3(2-5)$ & $0.4(0.1-0.8)$ & 14 & $0.03 \pm 0.02$ & $32 \pm 3$ \\
\hline 24 & 95 & $33(5-107)$ & $6(3-54)$ & 18 & $0.41 \pm 0.31$ & $58 \pm 11$ \\
\hline 25 & 669 & $130(18-543)$ & $105(76-133)$ & 80 & $0.31 \pm 0.36$ & $80 \pm 7$ \\
\hline 26 & 7,592 & $3,615(2,973-7,289)$ & $2,018(1,792-3,915)$ & 56 & $0.61 \pm 0.39$ & $50 \pm 4$ \\
\hline 27 & 624 & $41(4-1,859)$ & $33(12-55)$ & 82 & $0.78 \pm 1.2$ & $69 \pm 13$ \\
\hline 28 & 1,190 & nd & nd & nd & nd & $21 \pm 3$ \\
\hline 29 & 563 & $17(17-17)$ & $17(17-17)$ & 99 & $0.03 \pm 0$ & $68 \pm 9$ \\
\hline 30 & 1,326 & nd & nd & nd & nd & $39 \pm 8$ \\
\hline 31 & 559 & $43(1-178)$ & $1.6(0.5-76)$ & 4 & $0.12 \pm 0.14$ & $74 \pm 5$ \\
\hline 32 & 224 & $6(0-114)$ & $0.9(0.4-6.6)$ & 16 & $0.13 \pm 0.12$ & $49 \pm 15$ \\
\hline 33 & 2,098 & $26(17-68)$ & $17(6-29)$ & 64 & $0.02 \pm 0.02$ & $45 \pm 4$ \\
\hline 34 & 3,664 & $740(582-1,172)$ & $513(391-1,084)$ & 69 & $0.23 \pm 0.11$ & $67 \pm 6$ \\
\hline 35 & 1,718 & nd & nd & nd & $0.13 \pm 0.04$ & $41 \pm 20$ \\
\hline Runoff 1 & 0.008 & $0.0024(0.0005-0.0549)$ & $0.0023(0.0004-0.0548)$ & 96 & $2.70 \pm 2.58$ & \\
\hline Runoff 2 & 0.008 & $0.0552(0.0213-0.0704)$ & $0.0548(0.0210-0.0701)$ & 99 & $6.40 \pm 1.00$ & \\
\hline Runoff 3 & 0.008 & $0.0061(0.0030-0.0103)$ & $0.0059(0.0030-0.0103)$ & 97 & $0.81 \pm 0.12$ & \\
\hline
\end{tabular}

$n d$ not determined due to lack of discharge data or associated water chemistry 
Table 2 Annual discharge summary, and discharge characteristics, annual TP, FRP, and FRP/TP ratio and SS loads, for the Kalgan River

\begin{tabular}{|c|c|c|c|c|c|c|c|c|}
\hline Year & Flow (gigalitres) & $\begin{array}{l}\text { Number of } \\
\text { flow events }\end{array}$ & $\begin{array}{l}\text { Days where mean daily } \\
\text { flow }{ }^{b}>10 \mathrm{~m}^{3} \mathrm{~s}^{-1}\end{array}$ & $\begin{array}{l}\text { Maximum annual } \\
\text { flow rate }\left(\mathrm{m}^{3} \mathrm{~s}^{-1}\right)\end{array}$ & $\begin{array}{l}\text { TP load } \\
\text { (tonnes) }\end{array}$ & $\begin{array}{l}\text { FRP load } \\
\text { (tonnes) }\end{array}$ & $\begin{array}{l}\mathrm{FRP} / \mathrm{TP} \\
\operatorname{load}(\%)\end{array}$ & $\begin{array}{l}\text { SS load } \\
\text { (tonnes) }\end{array}$ \\
\hline 1987 & 10 & 0 & 0 & 2.1 & 0.3 & $0.2^{\mathrm{c}}$ & 51 & $29^{d}$ \\
\hline 1988 & 113 & 9 & 31 & 117.8 & 42.8 & $6.5^{\mathrm{c}}$ & 15 & $10,294^{\mathrm{d}}$ \\
\hline 1989 & 25 & 0 & 0 & 6.8 & 1.0 & $0.4^{\mathrm{c}}$ & 41 & $162^{\mathrm{d}}$ \\
\hline 1990 & 46 & 1 & 7 & 59.7 & 8.9 & $3.3^{\mathrm{c}}$ & 37 & $3,827^{\mathrm{d}}$ \\
\hline 1991 & 64 & 2 & 14 & 130.6 & 32.0 & $7.2^{\mathrm{c}}$ & 23 & $11,962^{\mathrm{d}}$ \\
\hline 1992 & 75 & 4 & 22 & 60.7 & 9.6 & 2.8 & 29 & 4,550 \\
\hline 1993 & 94 & 8 & 25 & 54.1 & 11.7 & 3.7 & 32 & 2,840 \\
\hline 1994 & 37 & 2 & 5 & 21.6 & 2.5 & 1.5 & 60 & 740 \\
\hline 1995 & 25 & 0 & 0 & 10.1 & 0.9 & 0.6 & 67 & 280 \\
\hline 1996 & 41 & 3 & 4 & 18.5 & 1.5 & 0.7 & 47 & 850 \\
\hline
\end{tabular}

${ }^{a}$ Events characterised by maintenance of mean daily flow rate above $10 \mathrm{~m}^{3} \mathrm{~s}^{-1}$ for one or more consecutive days

${ }^{\mathrm{b}}$ Total number of days where the mean daily flow rate exceeded $10 \mathrm{~m}^{3} \mathrm{~s}^{-1}$

${ }^{\mathrm{c}}$ Estimated from a relationship between FRP and maximum annual flow rate for $1992-1996 . \mathrm{FRP}=0.038+0.0552 \times \mathrm{MaxQ} . R^{2}=0.86$

${ }^{\mathrm{d}}$ Estimated from a relationship between SS and maximum annual flow rate for $1992-1996 . \log (\mathrm{SS})=0.997+1.456 \times \log (\mathrm{MaxQ}) . R^{2}=0.98$

Data analysis

Summary statistics such as means, medians, ranges, $95 \%$ confidence intervals and correlation and regression equations and statistics were calculated using DataDesk (Data Description 1996) and by the application of standard statistical methods described by Helsel and Hirsch (1992). Graphics, box and whisker plots, distribution plots, percentiles and related statistics were prepared using Aabel (Gigawiz Ltd. Co. 2013) and EazyDraw (Dekorra Optics LLC 2013), and maps were prepared using Quantum GIS (QGIS Development Team 2013). Flow and load data were derived using Hydstra/TS (Kisters Pty Ltd 2013).

\section{Results and discussion}

\section{Hillslope P transport}

Across all events, sites and treatments, significantly more water was leached than was delivered as surface runoff. Twenty-three times as much water was collected as leachate than runoff (Fig. 2a). This suggests that in this region for these experimental conditions, significantly more water travels vertically, rather than across the soil surface. The dominance of leaching as a transport vector is further reinforced in Fig. $2 b$ which shows the annual rainfall at each site for each year of the trial in the context of distributions of long-term rainfall since 1890 and reduced rainfall since 1975 (IOCI 2010). For rainfall since 1890 , the annual rainfall during the trial years was $>50$ th percentile for site 1 and approximately 75th percentile for sites 2 and 3. For rainfall since 1975, annual rainfall at each site was $>90$ th percentile in year 1 and approximately 75 th percentile in year 2 . Hence, whilst the years of the trials represented years where the likelihood of runoff was high, leaching was still the dominant process (Fig. 2a). This is consistent with the sandy texture of the soils, indicating a high winter rainfall infiltration. It is possible that rainfall may reemerge further down the hillslope; however, leaching appears to be the dominant process in these sandy soils in these landscapes at the local scale. Nutrient transport losses at the hillslope scale are therefore more likely to be dominated by FRP than PP, influencing nutrient management practice performance.

Despite water yield data being consistent across all sites, there were some site and hydrological vectorspecific differences in runoff or leachate $\mathrm{P}$ concentrations (Fig. 3a, b) that can be partly explained by different soil characteristics (Table 3 ). For example, site 2 showed no significant difference between leaching and runoff FRP concentrations. This may be due to higher PSR, suggesting that the top $10 \mathrm{~cm}$ of soil may be uniformly saturated with $\mathrm{P}$, and hence, rainfall interaction with the 


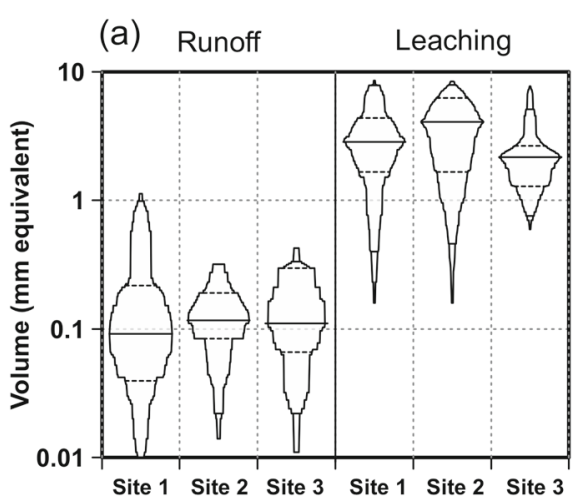

Fig. 2 a Distribution plots showing volumes (millimetre equivalent) delivered via runoff or leaching vectors for sampling events at each runoff trial site and $\mathbf{b}$ distribution plots of long-term annual rainfall since 1890 at each site (unfilled), distribution plots of annual rainfall since 1975 at each site (filled grey), overlayed with

surface layers will make little difference in FRP concentrations. In contrast, site 1 showed significantly higher FRP concentrations in surface runoff than in leachate. This site has the lowest PSR and hence is most likely to show strong stratification in soil $\mathrm{P}$ storage and $\mathrm{P}$ sorption with depth (Weaver et al. 1994; Dougherty et al. 2006), with low PSR arising because of dilution from very low PSR soil below the surface and higher PSR soil in the top few centimetres. Rainfall generating surface runoff would interact with high PSR soil in the top few centimetres, whilst rainfall generating leachate would interact overall with a lower PSR soil. Surface runoff would therefore result in FRP concentrations greater than those found in leachate. Sites 2 and 3 had higher PSR values than site 1 and generally showed higher FRP concentrations in leachate than site 1. That is, higher FRP concentrations were generally found in leachates with higher PSR values.

There were small differences between FRP and TP concentrations in surface runoff, indicating that a significant proportion of surface runoff $P$ was as FRP. Independent of site and treatment, the median ratio of FRP to TP was $60 \%$ (Fig. 4). Based on mean values of TP and FRP in surface runoff at site $1,42 \%$ of the $P$ was FRP compared to $75 \%$ at site 2 and $73 \%$ at site 3. Differences between FRP and TP in surface runoff observed at site 1 are likely to be due to higher $\mathrm{P}$ sorption characteristics (Amox Fe, Amox Al, PRI), TP and Colwell P (Table 3). Discharge of particulates and PP in surface runoff at site 1 would contribute to TP, explaining the largest difference observed between FRP and TP of all of the sites. As site 1 contains the most soil P, particulate (b)

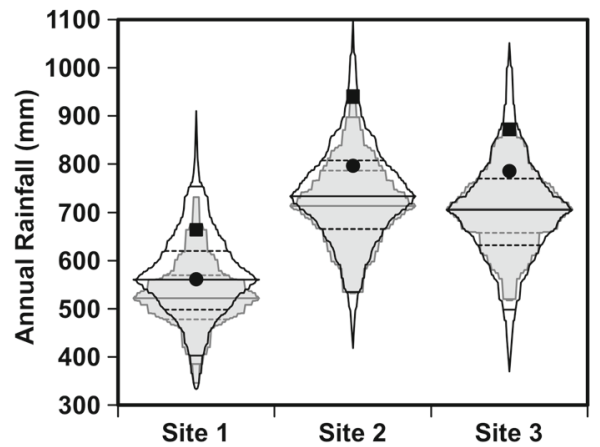

annual rainfall in year 1 (filled square) and year 2 (filled circle) of the trials. Distribution plots range from minimum to maximum, with dashed horizontal lines showing 5th, 25th, 50th, 75th and 95th percentiles

matter lost from the surface at site 1 is likely to discharge more PP than those indicated by the values in Table 3 because of stratification (Weaver et al. 1994; Dougherty et al. 2006) and enrichment due to selective loss of finer particulates during erosion (Quinton et al. 2001). However, particulate transport at site 1 is likely to be moderated by the low slope (Table 3 ). Hence, P mobilised in surface runoff from site 1 may contain FRP due to high soil $\mathrm{P}$ and $\mathrm{P}$ desorption from P-saturated surface soil; however, particulate matter contributing to TP may also resorb some of the mobilised FRP. At site 1 therefore, the difference between FRP and TP may not be as great as expected because of limited delivery of particulate matter due to low slopes. Figures 3a, b and 4 collectively indicate that FRP fractions are a major component of the $P$ forms in both surface runoff and leachate, except where these can be moderated by passing through high P-fixing soil materials (site 1) or where fine enriched particulate material can both contribute to TP and moderate FRP concurrently.

Overall, there were no significant influences of the addition of $\mathrm{P}$ on FRP or TP concentrations compared to where no P was added (Figs. 3a and 4). A separation between the closed and open symbols in Fig. 4 would be expected if there was an influence of fertiliser $\mathrm{P}$ addition on $\mathrm{P}$ concentrations. This is not evident for reasons including (1) the lack of coincidence between fertiliser addition and significant rainfall events (Dougherty et al. 2011a), resulting in incorporation of applied $\mathrm{P}$ into the agricultural soils and plants, and (2) the fertiliser P additions $(<10 \mathrm{mg}$ $\mathrm{P} \mathrm{kg}^{-1}$ ) are small compared to the $\mathrm{P}$ stored (78-460 mg $\mathrm{P} \mathrm{kg}^{-1}$ ) in these fertile agricultural soils (Table 3). 
Fig. 3 Box and whisker plots of a $\mathrm{P}$ concentrations (milligrams per litre) and $\mathbf{b}$ loads (kilograms per hectare) of FRP and TP for samples collected as leachate or runoff at each site over the 2-year monitoring period with $(+)$ or without (-) P added. Whiskers show 10th and 90th percentiles, and boxes show 25th, 50th and 75th percentiles. Circles show outliers (a)

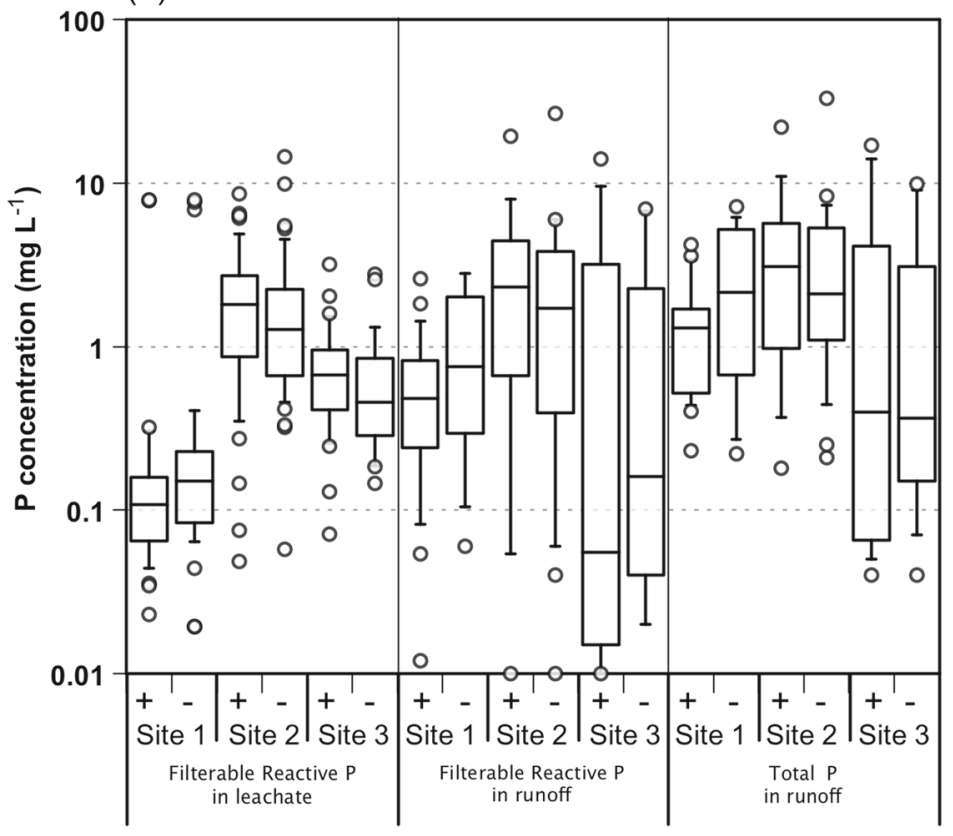

(b)

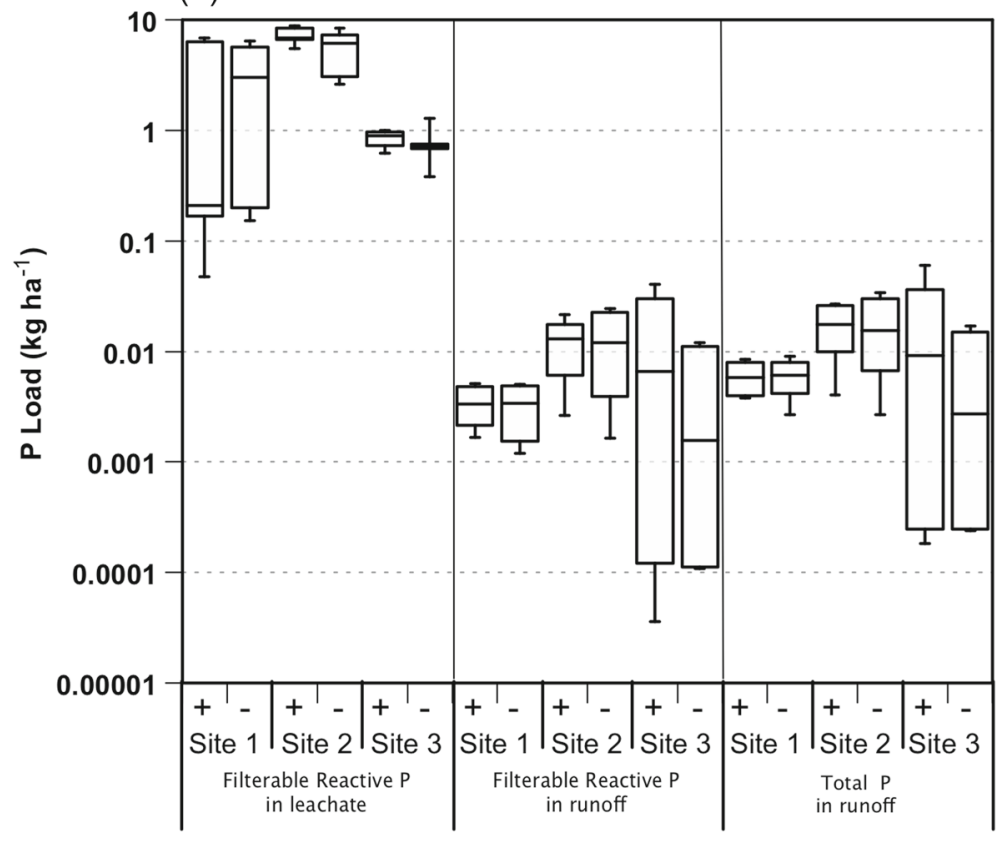

Given that there are major differences in the volumes of leachate and runoff at each site (Fig. 2), and little difference in FRP concentrations in leachate and runoff (Fig. 3a), the loads of FRP lost via leaching and runoff vectors were driven strongly by volume. The variation and magnitude of FRP and TP loads for each plot in each year delivered via different pathways shows that FRP loads in leachate were on average 2 orders of magnitude higher than FRP or TP in runoff (Fig. 3a, b). This is largely a function of greater volumes delivered via leaching pathways. This is further shown in Fig. 5 where there is a clear separation of FRP load for leachate and runoff events, with leachate providing significantly greater volumes and loads. It follows that these systems under the measured conditions are predisposed to deliver largely FRP via leaching. 
Table 3 Soil chemical and physical characteristics of the $0-10-\mathrm{cm}$ layer at each runoff trial site

\begin{tabular}{|c|c|c|c|}
\hline Parameter & Site 1 & Site 2 & Site 3 \\
\hline Texture (surface soil) & Sandy loam & Sandy loam & Sandy loam \\
\hline $\mathrm{pH}\left(\mathrm{CaCl}_{2}\right)$ & 5.1 & 4.8 & 4.4 \\
\hline $\operatorname{Amox} \mathrm{Al}\left(\mathrm{mg} \mathrm{kg}^{-1}\right)$ & 2,600 & 180 & 110 \\
\hline $\operatorname{Amox} \mathrm{Fe}\left(\mathrm{mg} \mathrm{kg}^{-1}\right)$ & 440 & 240 & 100 \\
\hline Colwell P (mg kg $\left.{ }^{-1}\right)$ & 54 & 32 & 13 \\
\hline Total P (mg kg $\left.{ }^{-1}\right)$ & 460 & 180 & 78 \\
\hline PRI (mL g $\left.{ }^{-1}\right)$ & 64 & -1.1 & -0.9 \\
\hline PSR & 1.7 & 7.1 & 9.4 \\
\hline Phosphorus status & High & High & High \\
\hline Slope $(\%)$ & 0.6 & 1.9 & 1.9 \\
\hline
\end{tabular}

Overall, the high proportion of P lost as FRP via leaching pathways and small amounts of PP transported via runoff pathways translates into a 96 to $99 \%$ of P lost as FRP via all measured pathways (Table 1).

Losses via surface runoff are also dominated by FRP as shown by the similarity between FRP and TP loads in surface runoff, but these are moderated where P retention capacity remains in the soil. Over the life of the experiment, site 1 delivered $56 \%$ of its $\mathrm{P}$ load in surface runoff as FRP whilst sites 2 and 3 delivered $75 \%$. This has implications for riparian buffers since most $\mathrm{P}$ is transported as FRP, and most likely via subsurface

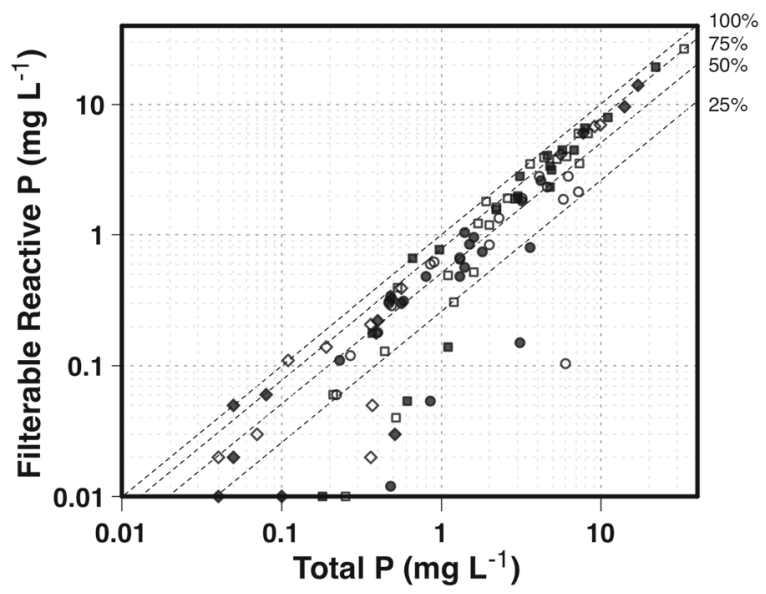

Fig. 4 Filterable reactive $\mathrm{P}$ concentration (milligrams per litre) in surface runoff for site 1 (circles), site 2 (squares) and site 3 (diamonds) as a function of total $\mathrm{P}$ concentration (milligrams per litre) per sampled runoff event for plots with (open symbols) or without (closed symbols) P added. Dashed isolines show specified proportions of runoff samples as FRP transport pathways (McKergow et al. 2006a, b). The physical filtering opportunities provided by riparian buffers would therefore be bypassed, and even where surface runoff was occasionally a more dominant process (site 1), significant amounts of the transported $\mathrm{P}$ were in a FRP form (Figs. 3a and 4) which would not be filtered by buffers. Riparian buffers in this environment will therefore do little to filter FRP delivered via surface runoff (Fig. 4) and will also be unable to moderate most of the $\mathrm{P}$ transported via leaching (Figs. $3 \mathrm{~b}$ and 5).

\section{Catchment $\mathrm{P}$ transport}

The median P load increased with increasing catchment size (Table 1) for both FRP (log FRP load $=0.689 \times \log$ area $\left.-0.461, R^{2}=0.67\right)$ and TP $(\log$ TP load $=0.737 \times \log$ area $\left.-0.146, R^{2}=0.75\right)$, and similar relationships have been reported elsewhere (Prairie and Kalff 1986). There was a considerable variation in annual $\mathrm{P}$ loads, which translated into a wide range for the $95 \%$ confidence intervals for the median values of TP and FRP. The FRP/ TP load ratio (an indicator of the percentage of soluble P) varied across catchments and ranged from 4 to $99 \%$, with a mean value of $45 \%$. A regression of median FRP load as a function of median TP load (not shown) suggests that $41 \%$ of the P load is FRP and is consistent with the large-scale modelled estimates of $34 \%$ from NLWRA (2001). This implies that around $40 \%$ of the P loads in this study area for catchments from 100245,000 ha are measured as FRP, and the other $60 \%$

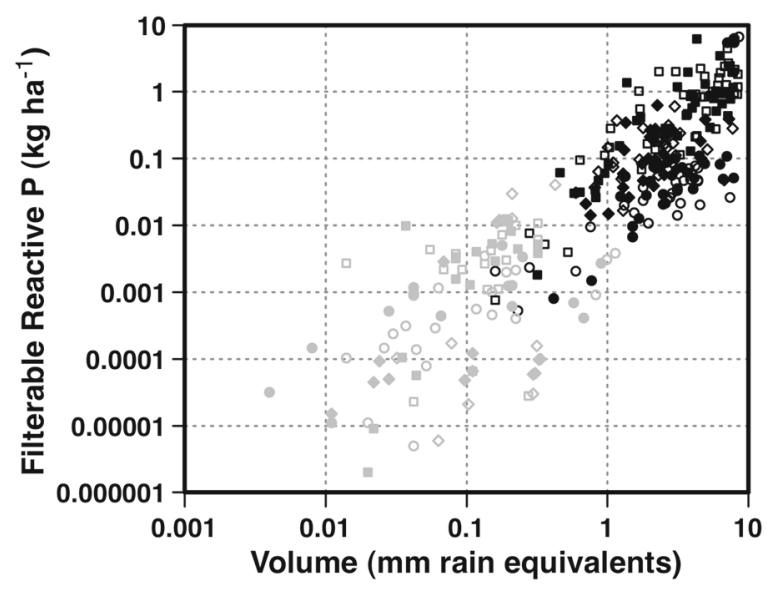

Fig. 5 Filterable reactive $\mathrm{P}$ loads (kilograms per hectare) for site 1 (circles), site 2 (squares) and site 3 (diamonds) as a function of volumes discharged per event (millimetres of rainfall equivalents) as runoff (grey symbols) or leachate (black symbols) for plots with (open symbols) or without (closed symbols) P added 
are therefore PP. The larger catchments (sites 6, 9 and 13) all had similar proportions $(27,31$ and 25 , respectively) of the measured P load as FRP, whilst the remaining smaller catchments $(<7,500$ ha) ranged from 4 to $99 \%$ of the P load as FRP. Site 29 and site 1 had 99 and $73 \%$ of the P load as FRP, respectively, and were known to be influenced by primary treated sewerage and discharge from a piggery. This partially explains the high FRP percentage, whilst most other catchments are influenced predominantly by diffuse agricultural nutrient sources. Table 1 also shows the mean and $95 \%$ confidence interval of FRP/TP concentration ratios. In many cases, these FRP/TP concentration ratios are greater than the equivalent FRP/TP load ratio, and across all subcatchments and catchments, the mean FRP/TP concentration ratio was $57 \%$. The lower FRP/ TP load ratio is to be expected since load calculations account for variations in both volume and concentration. Changes in volume and concurrent changes in P concentrations and the ratio of FRP/TP will lead to FRP/TP load ratios that are different to FRP/TP concentration ratios. For example, higher flow or poor management usually increases suspended material that would decrease the FRP/TP concentration ratio and, overall, reduce the FRP/TP load ratio (McKergow et al. 2003). This is evident in Table 2 for the Kalgan River where flow is positively correlated with SS loads (Spearman's rank correlation $=0.784, P<0.01$ ) and TP loads (Spearman's rank correlation $=0.948, P<0.001)$ and negatively with $\mathrm{FRP} / \mathrm{TP}$ load ratios (Spearman's rank correlation= $-0.845, P<0.01)$. Compared to years of higher flow showing FRP/TP load ratios of approximately $30 \%$, years of lower flow (1994-1996) show higher FRP/TP load ratios (47-67\%), fewer flow events of shorter duration and lower maximum annual flow rates. The years of higher flow had more flow events of longer duration and higher maximum annual flow rates.

Catchment-scale data (Tables 1 and 2) is sometimes misinterpreted to conclude that $\mathrm{P}$ is mobilised and transported from hillslopes to streams in a PP form (that is not leached and with low FRP/TP ratios), commensurate with water quality measurements observed at the large catchment scale. However, in-stream water quality values and $\mathrm{P}$ forms can be further influenced by instream factors (McDowell et al. 2004), and hence, without hillslope scale data, it is possible to erroneously conclude that water quality measurements at the catchment scale reflect nutrient mobilisation processes in operation at the hillslope scale. For these study catchments, using the large catchment-scale data alone, we may erroneously conclude that surface runoff and erosion is the dominant hillslope mobilisation process for P delivery since measurements showed $40 \%$ FRP on average; however, the runoff plots had 96 to $99 \%$ of the P lost as FRP. Using the catchment-scale data alone could lead to the incorrect conclusion and that riparian buffers would reduce P loss from the study catchments. In contrast to the commonly reported model of $\mathrm{P}$ mobilisation and transport by surface runoff and erosion, the data presented here may be interpreted by alternative models as follows: (1) P transport vectors differ in years dominated by different hydrological processes. Years where runoff is dominant would result in high PP loads and low FRP/TP load ratios, whilst years where leaching is dominant would lead to low PP loads and higher FRP/TP load ratios since leaching processes deliver mostly FRP (Table 2), and (2) stream sediment contributes, either through remobilisation and/or bank erosion, to increased SS loads and reduced FRP/TP load and concentration ratios in years of high flow because of in-stream P sorption. This alternative explanation may also be coupled with the notion that FRP lost from the landscape combines with stream sediment to provide varying FRP/TP signatures (Table 1, "P characteristics of catchment and stream bank soils" of the "Results and discussion" section). Each of these alternatives seems plausible in addition to the standard model of erosion of particulates from the landscape surface as the dominant process of $\mathrm{P}$ delivery and cause of water quality signatures measured in streams.

A comparison of the data collected from the runoff plots and the catchment-scale water quality measurements suggests a change in measures of P form from 96 to $99 \%$ FRP at the hillslope scale to on average $40 \%$ FRP at the large catchment scale (Table 1). This comparison suggests an influence of the stream network on $\mathrm{P}$ form and implies that measures of $\mathrm{P}$ form at the large catchment scale are not always indicators of nutrient loss mechanisms or of the potential success of management actions (Haggard and Sharpley 2007). The data also suggests that FRP lost from the landscape combines with in-stream sediment sources to provide the water quality signatures of $40 \% \mathrm{FRP}$ and $60 \% \mathrm{PP}$ at the large catchment scale. This is consistent with NLWRA (2001, 2002), which suggests that only $3 \%$ of $P$ is lost as hillslope PP and that $96 \%$ of SS is derived from gully and bank erosion. This is further supported by the relationship between TP load and catchment size in this 
study $\left(\log\right.$ TP $\operatorname{load}=0.737 \times \log$ area $\left.-0.146, R^{2}=0.75\right)$, where a slope less than unity leads to decreasing losses of $\mathrm{P}$ per unit area as catchment size increases. At the smallest scale, runoff plots (0.008 ha) measured an average loss of $3.3 \mathrm{~kg} \mathrm{P} \mathrm{ha}^{-1}$, catchments from 100 3,500 ha measured an average loss of $0.35 \mathrm{~kg} \mathrm{P}^{-1}$, catchments from 3,500-64,000 ha measured an average loss of $0.13 \mathrm{~kg} \mathrm{P} \mathrm{ha}^{-1}$ and catchments greater than 64,000 ha measured an average loss of $0.04 \mathrm{~kg} \mathrm{P} \mathrm{ha}^{-1}$. These systematic decreases in unit area $\mathrm{P}$ load with increasing catchment size are unlikely to be due to dilution alone, and therefore, $\mathrm{P}$ lost from the landscape principally as FRP will be converted to PP within the stream and be subsequently assimilated and/or remobilised within the stream network through sedimentation and other processes (Prairie and Kalff 1986; Haggard and Sharpley 2007). This is consistent with NLWRA (2001) for south-west WA and Keipert et al. (2008) and Rivers et al. (2013) for the Peel Harvey catchment, who suggested that 39 and $20 \%$ respectively of the mobilised $\mathrm{P}$ is delivered to catchment outlets, with the remainder retained in the hydrologic network.

$\mathrm{P}$ characteristics of catchment and stream bank soils

Catchment soils have more TP and Colwell $\mathrm{P}$ than whole stream bank soil (Fig. 6). The $<75-\mu \mathrm{m}$ fraction of stream bank soil had more TP and Colwell P than the whole stream bank soils and around the same TP and less Colwell P than catchment soils. Increasing TP with decreasing particle size has been reported previously (Syers et al. 1969). Catchment soils have less Amox $\mathrm{Fe}$ and Amox Al and lower PRI than whole stream bank soil, whilst the $<75-\mu \mathrm{m}$ fraction of stream bank soils had more Amox Fe and Amox Al and higher PRI than catchment soils or whole stream bank soils. Stream bank soils, particularly the $<75-\mu \mathrm{m}$ fraction that can remain suspended in flowing streams and rivers, therefore have a significant potential to retain FRP. Whole stream bank soils and the $<75-\mu \mathrm{m}$ fraction are much less saturated with $\mathrm{P}$ than catchment soils. This is reflected in the very low PSR and Colwell P/PRI ratio of whole stream bank soils and the $<75-\mu \mathrm{m}$ fraction compared with catchment soils. The much lower Colwell P/PRI ratio for stream bank soils is due to their higher PRI and lower Colwell P compared with catchment soils. The lower PRI and higher PSR of catchment soils are due to continued direct exposure of these materials to the application of P-based fertilisers (Weaver and Reed 1998; Weaver and
Wong 2011). Stream bank materials have limited direct exposure to the application of P-based fertiliser and are more likely to interact with $\mathrm{P}$ once it has been delivered to a stream. The low $\mathrm{P}$ content, high $\mathrm{P}$ sorption and low $\mathrm{P}$ saturation reinforces the notion that stream bank soils are more likely to retain $\mathrm{P}$ than contribute $\mathrm{P}$ as either $\mathrm{PP}$ or FRP. This is further reinforced by noting that the median TP content of whole stream bank soils in this study (94 mg P kg${ }^{-1}$ ) was almost an order of magnitude lower than that reported by Laubel et al. (2003) (640 mg $\mathrm{P} \mathrm{kg}^{-1}$ ) in a study where stream bank erosion contributed around half of the annual P load. Applying these findings to the potential for different soil materials to contribute to FRP (Moody 2011) or TP (Dougherty et al. 2011 b) shows that $>95$ and $>75 \%$ of catchment soils will exceed the FRP $\left(0.04 \mathrm{mg} \mathrm{P} \mathrm{L}^{-1}\right)$ target and TP (0.07 $\mathrm{mg} \mathrm{P} \mathrm{L}^{-1}$ ) water quality targets (ANZECC and ARMCANZ 2000), respectively. In contrast, $<10 \%$ of stream bank soils would exceed the TP target and around $10 \%$ of stream bank soils would exceed the FRP target. These findings are commensurate with those of Agudelo et al. (2011) who showed that catchment soils could maintain much higher equilibrium $P$ concentrations than deposited stream sediment or stream bank soils and that there was a potential that FRP released from deposited stream sediment could be adsorbed by stream bank materials. The low OC of whole stream bank soils and the $<75-\mu \mathrm{m}$ fraction compared to catchment soils is further evidence of their low fertility and suggests that they are largely mineral in origin. The broad chemical differences between these materials suggest that stream bank soils are exposed subsoil layers of common duplex (sand over clay) soils of the region that are depleted of P (McDowell et al. 2004). Stream bank soils are therefore more likely to retain $\mathrm{P}$ than contribute $\mathrm{P}$ directly as FRP or PP. This is supported by large-scale modeling for the south-west region of WA (NLWRA 2001) where it was reported that $14 \%$ of the $\mathrm{P}$ could be sourced from stream banks as PP. Catchment soils could contribute either PP or FRP; however, runoff plot data suggests that catchment soils are mainly a contributor of FRP.

Implications for the use of riparian buffers to manage $\mathrm{P}$ in catchments with sandy soils

A previous riparian study in south-west WA (McKergow et al. 2003) showed that after improved riparian management (i.e. fencing, stock exclusion and revegetation), catchment SS exports fell from a mean of 

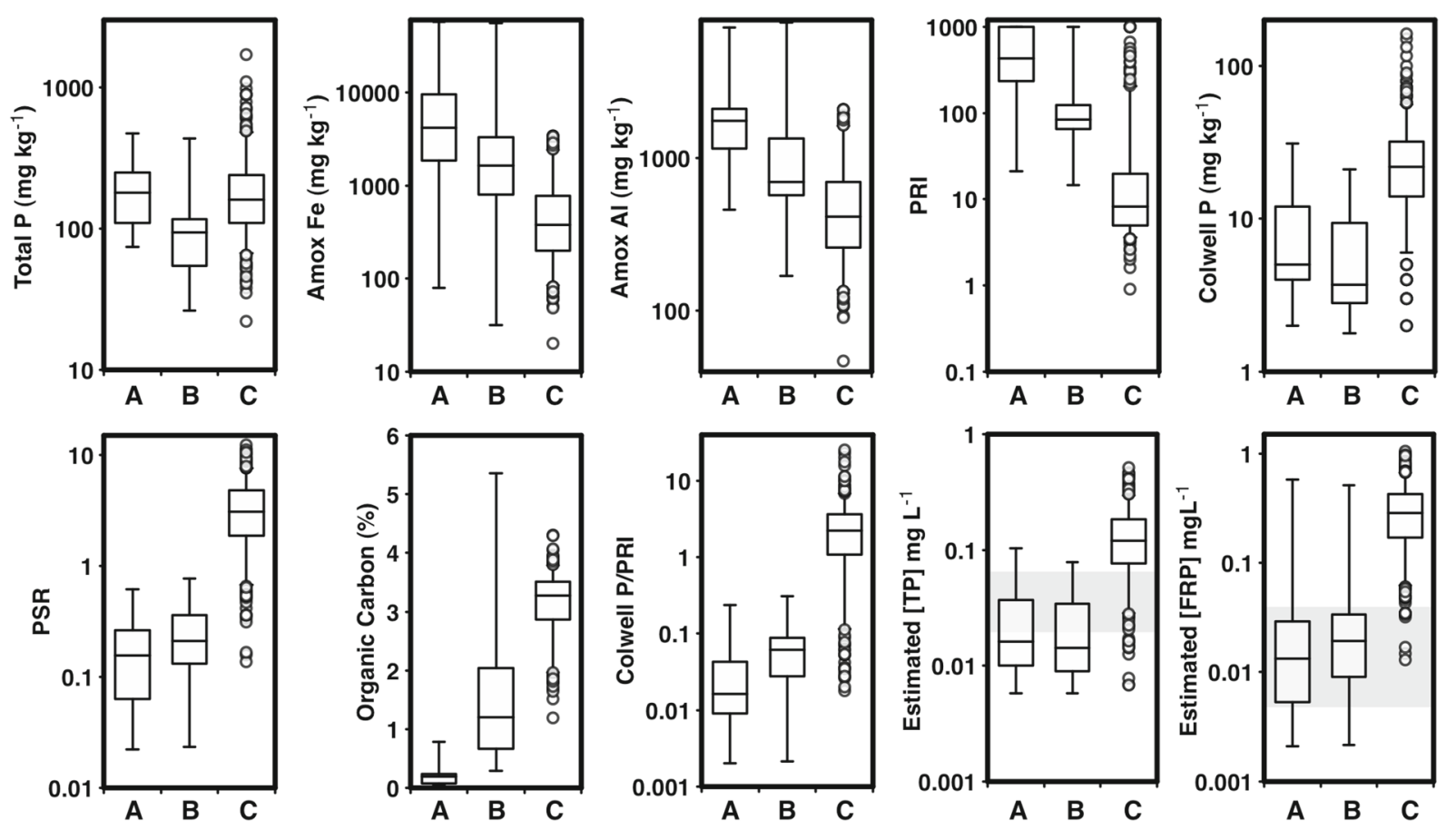

Fig. 6 Box and whisker plots comparing chemical characteristics of $(A)<75$ - $\mu \mathrm{m}$ fraction of stream bank soil, $(B)$ whole stream bank soil and $(C)<2-\mathrm{mm}$ fraction of catchment soils. Whiskers show 5 th

$150 \mathrm{~kg} \mathrm{ha}^{-1}$ year $^{-1}$ to less than $10 \mathrm{~kg} \mathrm{ha}^{-1}$ year $^{-1}$ due to reduced stream bank erosion. Whilst riparian buffers reduced total $\mathrm{N}(\mathrm{TN})$ by $25 \%$, they had no impact on TP and contributed to a $\mathrm{P}$ form change, where the median FRP increased by $70 \%$ as particulate P had been swapped for FRP (Stevens and Quinton 2008). Experiments of riparian hydrology and water quality in south-west WA (McKergow et al. 2006a, b) showed that the surface trapping efficiency of nutrients and sediment was consistent with other published data that measured surface trapping efficiency (Sharpley et al. 2002). Grass buffers trapped $53 \%$ of surface runoff, $54 \%$ of TP, $50 \%$ of FRP, $64 \%$ of SS and $58 \%$ of TN, whilst Eucalyptus globulus buffers trapped $-3 \%$ of surface runoff, $37 \%$ of TP, $11 \%$ of FRP, $21 \%$ of SS and $42 \%$ of TN. This compares well with the summarised data presented by Gitau et al. (2001) of TP removal by trees of $15 \%$ (range 5-50\%) and 50\% (range 40-70\%) by grass filter strips. The work of McKergow et al. (2006a, b) also included subsurface flow and water quality measurements and showed 20 times more flow and 3 times more $P$ discharged in subsurface flow than surface runoff (Fig. 7). Whilst $54 \%$ of the surface-derived TP was trapped by grass buffers, this is discounted to around and 95th percentiles, and boxes show 25th, 50th and 75th percentiles. Circles show outliers. Shaded areas show ANZECC/ ARMCANZ water quality targets for south-west WA

$10 \%$ when both transport vectors are considered. For each unit of $\mathrm{P}$ transported over the soil surface and reduced by $50 \%$ (or $37 \%$ for trees), further 3 units of $\mathrm{P}$ transported by subsurface pathways are not attenuated. These measurements reinforce the hillslope P transport ("Hillslope P transport" of the "Results and discussion" section) and catchment $\mathrm{P}$ transport ("Catchment P transport" of the "Results and discussion" section) data, indicating that significant amounts of water and $\mathrm{P}$ travel via leaching and subsurface pathways. Additionally, the measurements are supported by NLWRA (2001) reports of only $3 \%$ of P being sourced from hillslope PP in the region.

These previous riparian experiments can be interpreted in the context of the catchment ("Catchment P transport" of the "Results and discussion" section) and hillslope P transport ("Hillslope P transport" of the "Results and discussion" section) data and $\mathrm{P}$ characteristics of catchment and stream bank soils ("P characteristics of catchment and stream bank soils" of the "Results and discussion" section) to derive conceptual models of $\mathrm{P}$ management by riparian buffers in catchments with sandy soils. We hypothesise that prior to restoring riparian vegetation, FRP leached through the 
Surface flow and hillslope erosion dominated

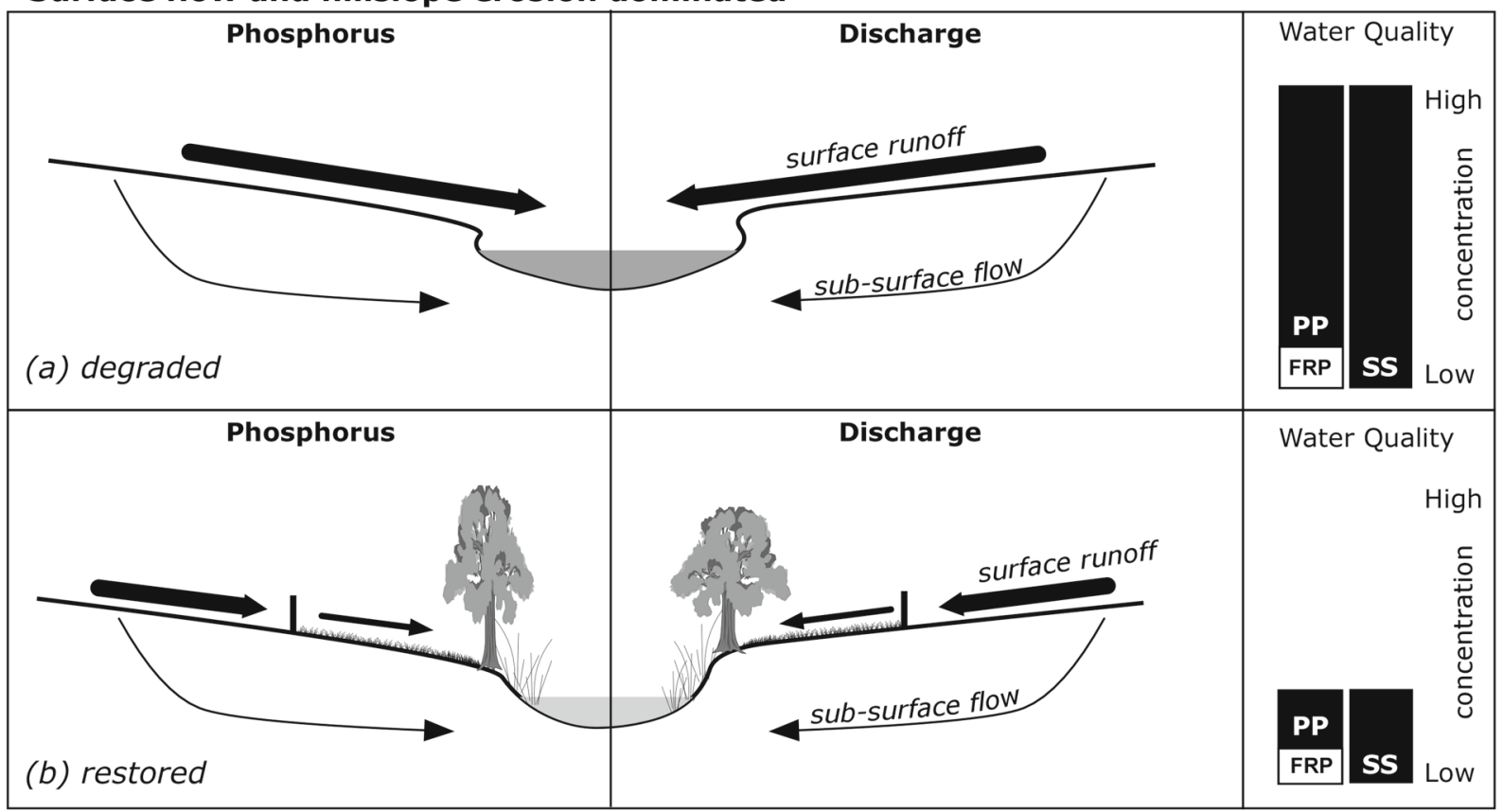

Sub-surface flow and gully erosion dominated

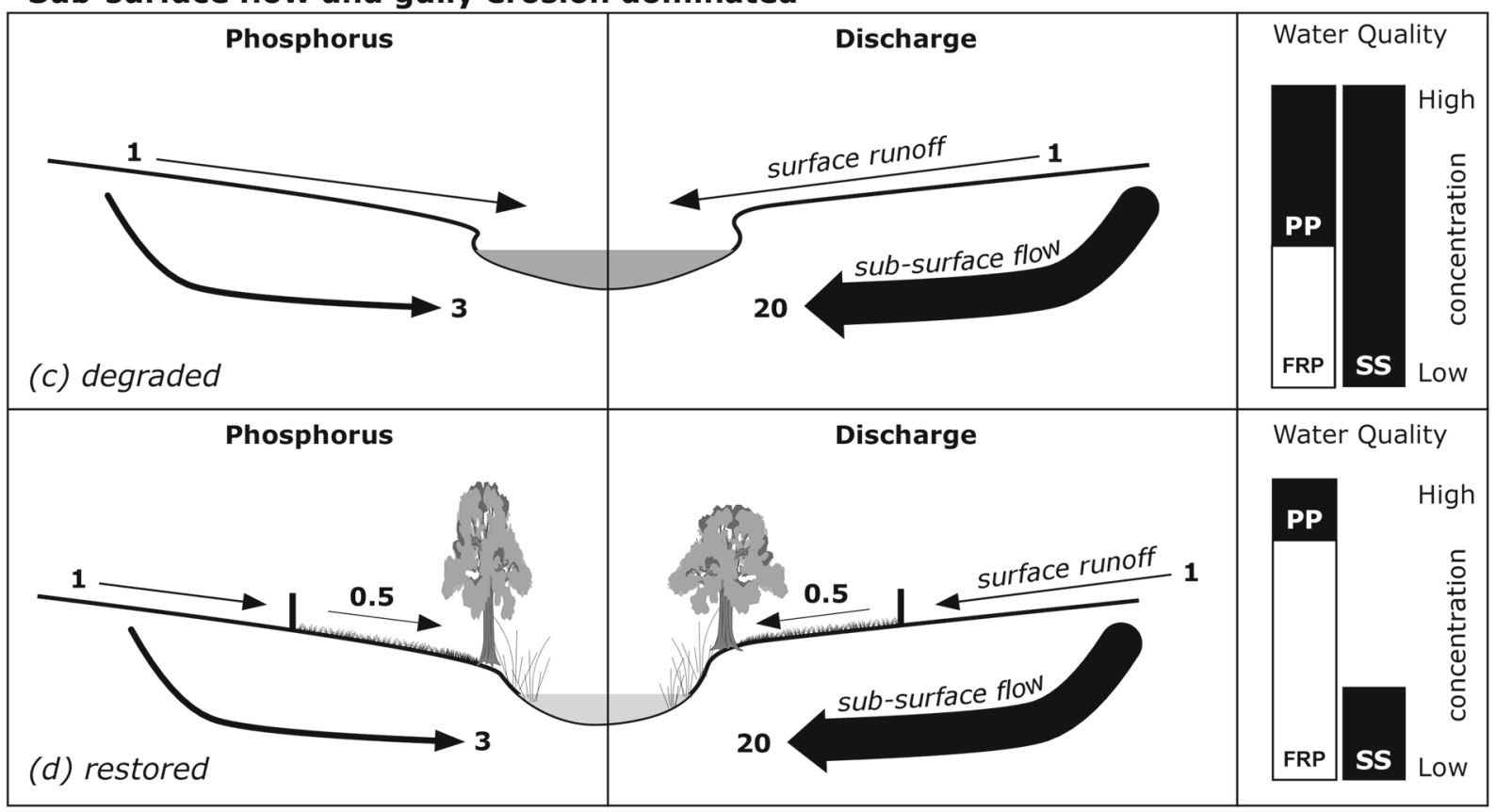

Fig. 7 Conceptual models of $\mathrm{P}$ transport and transformations before $(\mathbf{a}, \mathbf{c})$ and after $(\mathbf{b}, \mathbf{d})$ riparian management for systems dominated by surface transport processes $(\mathbf{a}, \mathbf{b})$ and subsurface transport processes $(\mathbf{c}, \mathbf{d})$. Width of arrows and number annotations indicate amounts of discharge or P transported via each pathway relative to surface runoff. Adapted from data presented by McKergow et al. (2003, 2006a, b)

signals at the catchment outlet (Fig. 7c). Restoring riparian vegetation and stock exclusion stabilised stream ways, and combined with available SS to give PP 
banks and cut off SS supply, reducing the capacity for FRP to be adsorbed on to stream-derived particulates. Hence, whilst SS transport had been stopped, the more bioavailable FRP continued downstream (Fig. 7d). This contrasts with the most commonly understood model of riparian function where improvements in water quality are brought about through physically filtering and trapping hillslope-derived particulates containing $\mathrm{P}$ in surface runoff. Additionally, this alternative model is consistent with the hillslope $\mathrm{P}$ transport results ("Hillslope $\mathrm{P}$ transport" of the "Results and discussion" section) that also suggest a leaching and subsurface flow system dominated by FRP. These results are in striking contrast to the conventional conceptual model of $\mathrm{P}$ transport and riparian function provided in Fig. 7a, b. In the conventional model, $\mathrm{P}$ transported across the soil surface in particulate matter is the major contributor to $\mathrm{P}$ pollution (Fig. 7a). Restoration of the riparian system would trap the surface-derived $\mathrm{P}$ by physically filtering the particulate matter and associated P (Fig. 7b). In this environment, the management practice of riparian buffers does not match the dominant transport pathway or nutrient form.

Implications arise for catchments dominated by subsurface transport pathways in relation to swapping PP for FRP, as well as changes in the N/P ratio of discharging waters. If riparian buffers are implemented extensively and function similarly as reported here, discharged nutrients may cause ecosystem responses worse than already observed. For example, increased FRP may increase the frequency and intensity of algal blooms, and large-scale changes in the N/P ratio may force aquatic ecosystems to support undesirable algal species that can fix $\mathrm{N}$ from the atmosphere if $\mathrm{N}$ became limiting due to a reduction in catchment $\mathrm{N}$ exports of $25 \%$.

These results also bring into question the interpretation of large catchment-scale water quality measurements in terms of the implied mobilisation and transport processes from those measurements. In this case, PP was around $50 \%$ of the TP (Fig. 7c) prior to implementing riparian buffers (McKergow et al. 2003). It could be assumed that surface runoff and erosion processes were responsible for the PP and, based on other published international research demonstrating the success of riparian buffers, that significant reductions in $\mathrm{P}$ transport would result. However, McKergow et al. (2003) showed that the removal of SS can lead to an increase in FRP. The runoff plot, catchment-scale water quality measurement and $\mathrm{P}$ retention and release characteristics of stream bank soils in this study point to a counter perspective - that the addition of SS could lead to a decrease in FRP and a proportional increase in PP in-stream.

Collectively, these studies demonstrate the importance of gaining an understanding of the prevailing hydrological and contaminant pathways within catchments, the nutrient retention and release characteristics of potential nutrient contributing materials, and nutrient transformations that may occur within stream systems prior to the wide-scale adoption of management practices. The results also imply that specific parts of catchments predisposed to surface transport processes and particulate nutrient transport would be the best candidates for riparian buffers if control of $\mathrm{P}$ was the aim. Ironically, retaining opportunities for SS in upstream P source areas of these catchments may assist to reduce downstream P transport. This would occur by adsorption of mobilised FRP to particulates that can then settle or be deposited onto floodplains by the longitudinal filtration of downstream intact riparian buffers. This is not an unreasonable assumption considering that NLWRA (2001) reports that only $39 \%$ of mobilised P in this region is exported to downstream waterbodies, with the remainder retained in the hydrologic network.

\section{Conclusion}

This paper takes data from a range of scales (in-stream potential for $P$ retention, hillslope runoff plots, small and large catchment water quality monitoring) that could be used to infer an a priori case that riparian buffers are likely to have limited effectiveness in reducing $P$ exports in catchments with sandy, low P sorption soils, where leaching of FRP is dominant. The findings help understand the processes behind previous reports of riparian ineffectiveness in this region. Before riparian buffers are recommended, investigations exploring riparian effectiveness, along with investigations that identify transport pathways and nutrient transformations, should be undertaken to help explain why riparian buffers may succeed or fail. This will assist to deliver a more costeffective allocation of management effort and expenditure to nutrient management. Ignoring subsurface transport pathways could lead to a significant overestimation of the effectiveness of riparian buffers in this environment as large amounts of $\mathrm{P}$ appear to be transported as FRP via leaching and subsurface pathways. Hence, riparian buffers do not satisfy fit-for-purpose requirements for $\mathrm{P}$ management under the range of conditions 
presented here. Changes in P from PP to FRP as a result of riparian restoration and from FRP to PP as measurement scale moves from hillslopes to catchments could be explained by the removal or addition of $\mathrm{P}$ retentive stream bank soil. These dynamic changes in water quality measurements bring into question the interpretation of water quality data as representing the processes by which $\mathrm{P}$ is mobilised and transported.

Acknowledgments The authors acknowledge the technical support of Adrian Reed and John Grant in the collection of data related to this paper. Data summarised from the work of Lucy McKergow is also acknowledged, as is catchment-scale water quality data made available from the Western Australian Department of Water via annual nutrient load reports to the community. Funding acknowledgements for previously reported and referenced work summarised in this paper should be sought from specifically cited references. The remaining aspects of this work were funded by the Western Australian Government.

Open Access This article is distributed under the terms of the Creative Commons Attribution License which permits any use, distribution, and reproduction in any medium, provided the original author(s) and the source are credited.

\section{References}

Agudelo, S. C., Nelson, N. O., Barnes, P. L., Keane, T. D., \& Pierzynski, G. M. (2011). Phosphorus adsorption and desorption potential of stream sediments and field soils in agricultural watersheds. Journal of Environmental Quality, 40, 144-152.

ANZECC and ARMCANZ (2000). Australian and New Zealand guidelines for fresh and marine water quality. Vol. 1. The guidelines. Australian and New Zealand Environment and Conservation Council and Agriculture and Resource Management Council of Australia and New Zealand, Canberra, ACT.

APHA. (1995). Standard methods for the examination of water and wastewater (19th ed.). Washington, DC: American Public Health Association.

AWMA (1995). Managing the Albany Waterways. Report to the Community 1995. Albany Waterways Management Authority, Albany, Western Australia.

Barling, R. D., \& Moore, I. D. (1994). Role of buffer strips in management of waterway pollution-a review. Environmental Management, 18, 543-558.

Bolland, M. D. A., \& Windsor, D. P. (2007). Converting reactive iron, reactive aluminium, and phosphorus retention index (PRI) to the phosphorus buffering index (PBI) for sandy soils of south-western Australia. Australian Journal of Soil Research, 45, 262-265.

Caitcheon, G., Donnelly, T., Wallbrink, P., \& Murray, A. (1995). Nutrient and sediment sources in Chaffey reservoir catchment. Australian Journal of Soil and Water Conservation, 8, 41-49.
Chrysostome, M., Nair, V. D., Harris, W. G., \& Rhue, R. D. (2007). Laboratory validation of soil phosphorus storage capacity predictions for use in risk assessment. Soil Science Society of America Journal, 71, 1564-1569.

Churchward, H. M., McArthur, W. M., Sewell, P. L. and Bartle, G. A. (1988). Landforms and soils of the south coast and hinterland, Western Australia (Northcliffe to Manypeaks). CSIRO, Division of Water Resources, Divisional Report 88/1.

Colwell, J. D. (1965). An automatic procedure for the determination of phosphorus in sodium hydrogen carbonate extracts of soil. Chemistry and Industrial, 10, 893-895.

Daniel, T. C., Sharpley, A. N., Edwards, D. R., Wedepohl, R., \& Lemunyon, J. L. (1994). Minimizing surface water eutrophication from agriculture by phosphorus management. Journal of Soil and Water Conservation, 49, 30-38.

Data Description (1996). DataDesk version 6.3. Data Description, PO Box 4555, Ithaca, NY. http://www.datadesk.com. Accessed 6 Nov 2013

Dekorra Optics LLC (2013). EazyDraw version 6.1. http://www. eazydraw.com. Accessed 6 Nov 2013

Department of Water (2010) Vasse Wonnerup wetlands and Geographe Bay water quality improvement plan. Department of Water, Perth, Western Australia. http://www.water.wa.gov. au/PublicationStore/first/92284.pdf. Accessed 17 Jul 2012

Department of Water (2011). Hardy inlet water quality improvement plan stage one-the Scott River catchment. Department of Water, Perth, Western Australia. http://www.water.wa.gov.au/PublicationStore/first/ 99276.pdf. Accessed 17 Jul 2012.

Dougherty, W. J., Nash, D. M., Chittleborough, D. J., Cox, J. W., \& Fleming, N. K. (2006). Stratification, forms, and mobility of phosphorus in the topsoil of a chromosol used for dairying. Australian Journal of Soil Research, 44, 277-284.

Dougherty, W. J., Burkitt, L. L., Corkery, R., \& Harvey, D. M. (2011a). The effect of soil P sorption properties and phosphorus fertiliser application strategy on 'incidental' phosphorus fertiliser characteristics: a laboratory study. Nutrient Cycling in Agroecosystems, 89, 189-197.

Dougherty, W. J., Mason, S. D., Burkitt, L. L., \& Milham, P. J. (2011b). Relationship between phosphorus concentration in surface runoff and a novel soil phosphorus test procedure (DGT) under simulated rainfall. Soil Research, 49, 523-528.

DSITIA (Department of Science, Information Technology, Innovation and the Arts, Queensland) (2013). http:// www.longpaddock.qld.gov.au/silo/. Accessed 6 Nov 2013

Environmental Protection Authority (2008) Water quality improvement plan for the rivers and estuary of the PeelHarvey system - phosphorus management. Environmental Protection Authority, Perth, Western Australia. http://www. epa.wa.gov.au/EPADocLib/Peel_Harvey_WQIP151208.pdf. Accessed 17 Jul 2012

Gigawiz Ltd. Co. (2013). Aabel version 3.06. Tulsa: Gigawiz Ltd. Co. http://www.gigawiz.com. Accessed 6 Nov 2013

Gitau, M. W., Schneiderman, E., Gburek, W. J., Jarrett, A. $R$ (2001). An evaluation of best management practices installed in the Cannonsville Reservoir Watershed, New York. In Proceedings of the ninth national non 
point source monitoring workshop, 27-30 August, Indianapolis, Indiana.

Gourley, C. J. P., Melland, A. R., Waller, R. A, Awty, I. M., Smith, A. P., Peverill, K. I., Hannah, M. C. (2007). Making better fertiliser decisions for grazed pastures in Australia. Melbourne: Victorian Department of Primary Industries. http://www.asris.csiro.au/downloads/BFD/ $\mathrm{M}$ a k i n g $20 \mathrm{~B}$ e t t e r $20 \mathrm{~F}$ e r t i 1 i s e r 20 Decisions20for20Grazed20Pastures20in20Australia.pdf. Accessed 6 Nov 2013

Guy, H. P. \& Norman, V. W. (1970). Field methods for measurement of fluvial sediment. Techniques of water-resources investigations of the United States Geological Survey. Chapter C2, book 3, Application of hydraulics. United States Government Printing Office, Washington.

Haggard, B. E., \& Sharpley, A. N. (2007). Phosphorus transport in streams: processes and modeling considerations. In D. E. Radcliffe \& M. L. Cabrera (Eds.), Modelling phosphorus in the environment (pp. 105-130). Boca Raton: CRC.

Helsel, D. R., Hirsch, R. M. (1992). Statistical methods in water resources. Studies in environmental science, vol. 49. U.S. Geological Survey, Water Resources Division, Reston, Virginia 22092, USA. New York: Elsevier.

Hoffmann, C. C., Kjaergaard, C., Uusi, K. J., Hansen, H. C. B., \& Kronvang, B. (2009). Phosphorus retention in riparian buffers: review of their efficiency. Journal of Environmental Quality, 38, 1942-1955.

IOCI (2010). Update on IOCI research: WA rainfall — what the past can tell us, and what the future may hold. http://www. ioci.org.au/pdf/Fact20Sheet204.pdf. Accessed 12 Sep 2011.

Keipert, N., Weaver, D., Summers, R., Clarke, M., \& Neville, S. (2008). Guiding BMP adoption to improve water quality in various estuarine ecosystems in Western Australia. Water Science and Technology, 57(11), 1749-1756.

Kisters Pty Ltd (2013) Hydstra/TS, Hydstra time-series data management software package. Citrus Heights: Kisters Pty Ltd. http://www.kisters.net/hydstra.html. Accessed 6 Nov 2013.

Laubel, A., Kronvang, B., Hald, A. B., \& Jensen, C. (2003). Hydromorphological and biological factors influencing sediment and phosphorus loss via bank erosion in small lowland rural streams in Denmark. Hydrological Processes, 17, 3443-3463.

Line, D. E., Harman, W. A., Jennings, G. D., Thompson, E. J., \& Osmond, D. L. (2000). Nonpoint-source pollutant load reductions associated with livestock exclusion. Journal of Environmental Quality, 29, 1882-1890.

Master, R. (2007). Oyster Harbour catchment appraisal. Resource management technical report 320. Department of Agriculture and Food Western Australia, Perth. http://www.agric.wa.gov. au/PC 92300.html?s=1545756909. Accessed 1 Jul 2012

McDowell, R. W., \& Sharpley, A. N. (2001). A comparison of fluvial sediment phosphorus $(\mathrm{P})$ chemistry in relation to location and potential to influence stream $\mathrm{P}$ concentrations. Aquatic Geochemistry, 7, 255-265.

McDowell, R. W., Biggs, B. J. F., Sharpley, A. N., \& Nguyen, L. (2004). Connecting phosphorus loss from agricultural landscapes to surface water quality. Chemistry and Ecology, 20, 1-40.

McKergow, L. A., Weaver, D. M., Prosser, I. P., Grayson, R. B., \& Reed, A. E. G. (2003). Before and after riparian management: sediment and nutrient exports from a small agricultural catchment, Western Australia. Journal of Hydrology, 270, 253-272.
McKergow, L. A., Prosser, I. P., Weaver, D. M., Grayson, R. B., \& Reed, A. E. G. (2006a). Performance of grass and eucalyptus riparian buffers in a pasture catchment, Western Australia, part 1: riparian hydrology. Hydrological Processes, 20, 2309-2326.

McKergow, L. A., Prosser, I. P., Weaver, D. M., Grayson, R. B., \& Reed, A. E. G. (2006b). Performance of grass and eucalyptus riparian buffers in a pasture catchment, Western Australia, part 2: water quality. Hydrological Processes, 20, 2327-2346.

Moody, P. W. (2011). Environmental risk indicators for soil phosphorus status. Soil Research, 49, 247-252.

Murphy, J., \& Riley, J. P. (1962). A modified single solution method for the determination of phosphate in natural waters. Analytica Chimica Acta, 27, 31-36.

Neville, S. D., Weaver, D. M., Ovens, R., Keipert, N., Summers, R. N. and Clarke, M. F. (2008). SSPND (Support System for Phosphorus and Nitrogen Decisions) modeling of management practices can guide the way ahead. In Conference proceedings of diffuse integrated pollution management (DIPCON), Thailand, September.

NLWRA (2001) Australian agriculture assessment 2001, vol. 1. National Land and Water Resources Audit, Land and Water Australia, Canberra, ACT. http://wa.gov.au/files/products/ national-land-and-water-resources-audit/pr010237/ pr010237.pdf. Accessed 14 Nov 2013.

NLWRA (2002). Australian catchment, river and estuary assessment 2002, vol. 2. National Land and Water Resources Audit, Land and Water Australia, Canberra, ACT. http:// lwa.gov.au/files/products/national-land-and-water-resourcesaudit/pr020283/pr020283.pdf. Accessed 29 Jul 2012

Omernik, J. M., Abernathy, A. R., \& Male, L. M. (1981). Stream nutrient levels and proximity of agricultural and forest land to streams: some relationships. Journal of Soil and Water Conservation, 36, 227-231.

Prairie, Y. T., \& Kalff, J. (1986). Effect of catchment size on phosphorus export. Water Resources Bulletin, 22, 465-470.

QGIS Development Team (2013). QGIS geographic information system. Open Source Geospatial Foundation Project. http:// qgis.osgeo.org. Accessed 6 Nov 2013.

Quinton, J. N., Catt, J. A., \& Hess, T. M. (2001). The selective removal of phosphorus from soil: Is event size important? Journal of Environmental Quality, 30, 538-545.

Rivers, M. R., Weaver, D. M., Smettem, K. R. J., \& Davies, P. M. (2013). Estimating farm to catchment nutrient fluxes using dynamic simulation modelling - can agri-environmental BMPs really do the job? Journal of Environmental Management, 130, 313-323.

Ruprecht, J. K., \& George, P. R. (1993). Hydrology of the PeelHarvey estuary catchment. Fertiliser Research, 36, 127-133.

Schoknecht, N. (2005). Soil groups of Western Australia, 3rd edn. Resource management technical report 246. Agriculture Western Australia, Perth. http:/www.agric.wa.gov.au/PC 92472.html?s=1545756909. Accessed 1 Jul 2012.

Sharpley, A. N., Chapra, S. C., Wedepohl, R., Sims, J. T., Daniel, T. C., \& Reddy, K. R. (1994). Managing agricultural phosphorus for protection of surface waters: issues and options. Journal of Environmental Quality, 23, 437-451.

Sharpley, A. N., Kleinman, P. J. A., McDowell, R. W., Gitau, M., \& Bryant, R. B. (2002). Modeling phosphorus transport in agricultural watersheds: processes and possibilities. Journal of Soil and Water Conservation, 57, 425-439. 
Stevens, C. J., \& Quinton, J. N. (2008). Policy implications of pollution swapping. Journal of Physics and Chemistry Earth, 34, 589-594.

Stone, M., \& Mudroch, A. (1989). The effect of particle size, chemistry and mineralogy of river sediments on phosphate adsorption. Environmental Technology Letters, 10, 501-510.

Stutter, M. I., Langan, S. J., \& Lumsdon, D. G. (2009). Vegetated buffer strips can lead to increased release of phosphorus to waters: a biogeochemical assessment of the mechanisms. Environmental Science and Technology, 43, 1858-1863.

Syers, J. K., Shah, R., \& Walker, T. W. (1969). Fractionation of Phosphorus in Two Alluvial Soils and Particle-Size Separates. Soil Science, 108, 283-289.

Tamm, O. (1922). Eine Methode zur Bestimmung de der anorganischen Komponente des Bodens. Meddelanden fran Statens skogsforsoksanstalt Stockholm, 19, 387-404.

van der Perk, M., Owens, P. N., Deeks, L. K., Rawlins, B. G., Haygarth, P. M., \& Beven, K. J. (2007). Controls on catchment-scale patterns of phosphorus in soil, streambed sediment, and stream water. Journal of Environmental Quality, 36, 694-708.
Walkley, A., \& Black, I. A. (1934). An examination of the Degtjareff method for determining soil organic matter, and a proposed modification of the chromic acid titration method. Soil Science, 37, 29-38.

Weaver, D. M., \& Reed, A. E. G. (1998). Patterns of nutrient status and fertiliser practice on soils of the south coast of Western Australia. Agriculture, Ecosystems and Environment, 67, 37-53.

Weaver, D. M., \& Wong, M. T. F. (2011). Scope to improve phosphorus (P) management and balance efficiency of crop and pasture soils with contracting $\mathrm{P}$ status and buffering indices. Plant and Soil, 349, 37-54.

Weaver, D. M., Pen, L. J., \& Reed, A. E. G. (1994). Modifying the phosphorus cycle to achieve management objectives in the Oyster Harbour catchment. Water, 21, 28-32.

Weaver, D. M., Neville, S., \& Deeley, D. M. (2005). Addressing off-site nutrient pollution through conventional management actions: a modelling case study. Australian Journal of Water Resources, 8, 165-178. 